\title{
ПОРІВНЯЛЬНА ОЦІНКА АНТИГІПЕРГЛІКЕМІЧНОЇ ТА АНТИОКИСЛЮВАЛЬНОÏ АКТИВНОСТІ МЕТАБОЛІТІВ СУКЦИНАТВМІСНОГО АНТИДІАБЕТИЧНОГО ЗАСОБУ
}

\author{
Палагіна I. A. \\ ДУ «Інститут проблем ендокринної патологї іл. В. Я. Данилевського НАМН України», \\ м. Харків, Україна \\ lab-tox@ukr.net
}

Цукровий діабет (ЦД) е одним з найбільш поширених ендокринних захворювань, яке, за даними ВООЗ, зареестровано у 463 млн людей віком 20-79 років у світі, 3 них близько 1,3 млн - в Україні. За даними статистики IDF прогнозуеться зростання кількості хворих на ЦД у 2030 році до 578 млн, що переважно стосуеться діабету 2 типу [1,2].

Причиною ранньої інвалідизації та високої смертності хворих на діабет е хронічні ускладнення, як серцево-судинна патологія, ниркова недостатність, ретинопатія 3 можливою втратою зору, периферична нейропатія з ризиком виразки стопи і навіть гангрени, тощо [3]. Універсальним пусковим механізмом ускладнень ЦД є надмірне утворення активних форм кисню (АФК) та оксиду азоту внаслідок гіперглікемії, підвищення інтенсивності вільнорадикального окиснення (ВРО) та при- гнічення антиоксидантної системи (АОС). В результаті пошкоджуються ліпідні та білкові компоненти клітин, генеруються продукти перекисного окиснення ліпідів (ПОЛ), окисної модифікації білків, токсичні метаболіти оксиду азоту (NO) [4].

Застосування антидіабетичних засобів (АДЗ), які мають антиоксидантну активність, може значно знижувати інтенсивність ВРО, ризик формування та розвитку діабетичних ангіопатій [5]. В ДУ «Інститут проблем ендокринної патології ім. В. Я. Данилевського НАМН України» синтезовано новий засіб з комплексними антидіабетичними властивостями на основі $\beta$-фенілетиламіда 2 -оксисукцинанілової кислоти ( певтичної дії якого є стимуляція біоенергетичних процесів, пригнічення оксидативного стресу (ОC) в мітохондріях, зниження неферментативного глікозилювання [6].

* Роботу виконано в межах планової наукової тематики ДУ «Інститут проблем ендокринної патології ім. В. Я. Данилевського НАМН України» «Визначення біологічної активності та безпечності продуктів біотрансформації антидіабетичного засобу фенсукциналу» (державний реєстраційний № 0111U000176).

Установою, що фінансує дослідження, є НАМН України.

Автор гарантуе повну відповідальність за все, що опубліковано в статті.

Автор гарантуе відсутність конфлікту інтересів і власної фінансової зацікавленості при виконанні роботи та написанні статті.

Рукопис надійшов до редакції 17.02.2021. 
В процесі біотрансформації в організмі лікарські засоби за участі ферментів мікросомальної монооксигеназної системи здебільшого інактивуються, але й, навпаки, можуть утворюватися їх активні токсичні метаболіти із зміненими, шкідливими властивостями [7]. Визначені метаболіти першої фази біотрансформації $\beta$-ФЕАОСАК: 2 -гідроксифеніл- (2-ГФСА) та $\beta$-фенілетилсукцинамід ( $\beta$-ФЕСА), які можуть проявляти антиокислювальну та антигіпергліке- мічну активність, а також робити певний внесок в реалізацію можливих побічних ефектів. Отже, з'ясування їх ролі у механізмі дії $\beta$-ФЕАОСАК представляе певний науковий інтерес.

Метою роботи було оцінити антиокислювальний та антигіперглікемічний потенціал 2-гідроксифеніл- та $\beta$-фенілетилсукцинаміда порівняно з їх вихідною сполукою - $\beta$-фенілетиламідом 2 -оксисукцинанілової кислоти.

\section{МАТЕРІАЛИ ТА МЕТОДИ}

Антигіперглікемічну активність 2-ГФСА та $\beta$-ФЕСА визначали в тесті толерантності до глюкози на щурах у порівнянні з активністю їх вихідної сполуки - $\beta$-ФЕАОСАК [8]. 2-ГФСА і $\beta$-ФЕСА вводили щурам перорально, відповідно, в дозах 17 мг/кг м.т. i 18 мг/кг м.т., які еквімолярні ефрективній дозі $\beta$-ФЕАОСАК, що дорівнюе 25 мг/кг м.т. Тварини отримували сполуки за 30 хвилин до введення глюкози в дозі 3 г/кг м.т. після чотирьох годин голодування. Рівень глікемії оцінювали в динаміці за показниками базальної глікемії та площі під глікемічною кривою, яку розрахували за допомогою комп'ютерної програми «Mathlab».

Визначення антиокислювальної активності (АОА) метаболітів $\beta$-ФЕАОСАК проведено in vitro на суспензії жовточних ліпопротеїдів (ЖЛП), які за ліпідним та білковим складом відповідають ліпопротеїдам низької та дуже низької щільності (ЛПНЩ, ЛПДНЩ) плазми крові. У пробах визначали рівні активних сполук, що реагують 3 тіобарбітуровою кислотою (ТБКАС), який е показником швидкості $\mathrm{Fe}^{2+}$-індукованого ПОЛ. Про ступінь сумарної АОА сполук судили за ефектом гальмування накопичення ТБКАС у суспензії ЖЛП. АОА виражали у відсотках інгібу- вання ПОЛ, що визначається як співвідношення ТБКАС, які утворюються у системі без антиоксиданта та у його присутності [9]. Антиокислювальну активність 2-ГФСА та $\beta$-ФЕСА досліджували у кінцевих концентраціях в інкубаційному середовищі від 25 до 500 мкМ. В якості сполуки порівняння застосовували $\beta$-ФЕАОСАК у тих же кінцевих концентраціях. Відповідні розчини сполук готували на диметилсульфоксиді 3 кінцевою концентрацією $1,68 \cdot 10^{-1} \mathrm{M}$.

Статистичну обробку даних експерименту проводили методами варіаційної статистики з використанням пакету програм Anova. Нормальність розподілу ознаки у виборці визначали за допомогою критерію Шапіро-Уілка (W). Для множинного порівняння показників, які характеризуються нормальним розподілом, проводили однофакторний дисперсійний аналіз та застосовували критерій Ст'юдента-Н'юменаКейлса [10]. Результати представлені у вигляді середнього арифметичного та його стандартної похибки $\left(\overline{\mathrm{X}} \pm \mathrm{S}_{\overline{\mathrm{X}}}\right)$. При перевірці статистичної гіпотези критичний рівень значущості приймали рівним $\mathrm{P} \leq 0,05$ Для оцінки залежності АОА від концентрації сполук затосовували кореляційно-регресійний аналіз [11].

\section{РЕЗУЛЬТАТИ ТА ЇХ ОБГОВОРЕННЯ}

Експериментально встановлено, що за рівнем базальної глікемії щури, які ізольовано отримували $\beta$-ФЕАОСАК або один з його метаболітів, не відрізнялись від тварин груп відповідного контролю. Тобто введення метаболітів суттево не впливало на рівень глікемії після глюкозного на- вантаження. Нормалізація рівня глюкози крові після глюкозного навантаження відбувалась одночасно - через годину у всіх піддослідних та контрольних групах. За показником площі під глікемічною кривою (ППК) також не було зареєстровано значущих відмінностей між тваринами, що 
отримували 2-ГФСА, $\beta$-ФЕСА, $\beta$-ФЕАОСАК та відповідним контролем (таблиця 1).

Отже, результати оцінки можливої антигіперглікемічної активності метаболітів $\beta$-ФЕАОСАК у порівнянні з самою вихідною сполукою показали, що досліджені сполуки не проявляють цього виду специфічної активності в тесті толерантності до глюкози.

Результати дослідження антиокислювальної активності 2-ГФСА, $\beta$-ФЕСА та $\beta$-ФЕАОСАК in vitro на суспезії ЖЛП наведені в таблиці 2. Максимальне значення сумарної АОА для 2-ГФСА складае $34,6 \%$ в концентрації 300 мкМ, для $\beta$-ФЕСА - 31,2\% в концентрації 250 мкМ. Для $\beta$-ФЕСА ступінь прояву АОА в концентрації 300 мкМ практично не змінюеться порівняно з концентрацією 250 мкM, дорівнюючи $30 \%$.

При додаванні до інкубаційного середовища $\beta$-ФЕАОСАК у тих же концентраціях, на рівні яких антиокислювальний ефект його метаболітів був максимальним, AOA цієї сполуки була вираженою і становила близько $72 \%$, більше ніж вдвічі

Рівень глікемії у щурів за впливу 2-ГФСА, $\beta$-ФЕСА та $\beta$-ФЕАОСАК

Таблиця 1 під час глюкозного навантажувального тесту $\left(\overline{\mathrm{X}}_{ \pm} \mathrm{S}_{\overline{\mathrm{X}}}\right), \mathbf{n}=\mathbf{6}$

\begin{tabular}{|c|c|c|c|c|c|c|}
\hline \multirow{2}{*}{$\begin{array}{c}\text { Група } \\
\text { тварин }\end{array}$} & \multirow{2}{*}{$\begin{array}{c}\text { Базальна } \\
\text { глікемія }\end{array}$} & \multicolumn{4}{|c|}{ Рівень глюкози крові, ммоль/л через } & \multirow{2}{*}{$\begin{array}{c}\text { ППК }{ }^{1)}, \\
\text { ммоль/л'хв }\end{array}$} \\
\hline & & $15 \times \mathrm{B}$ & $30 \times \mathrm{B}$ & $45 \times B$ & $60 \times B$ & \\
\hline Контроль & $43+04$ & $9,1 \pm 1,3$ & $6,8 \pm 0,6$ & $5,4 \pm 0,2$ & $4,4 \pm 0,3$ & $368,1 \pm 28,7$ \\
\hline 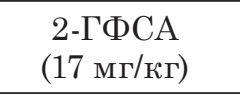 & $4,7 \pm 0,4$ & $10,9 \pm 0,5$ & $7,5 \pm 0,4$ & $6,3 \pm 0,5$ & $5,1 \pm 0,3$ & $443,7 \pm 15,1$ \\
\hline Контроль & $4,04 \pm$ & $11,9 \pm 0,7$ & $8,77 \pm 0,87$ & $5,74 \pm 0,89$ & $5,33 \pm 0,70$ & $310,6 \pm 25,3$ \\
\hline $\begin{array}{c}\beta-\Phi Е С А \\
(18 \text { мг/кг) }\end{array}$ & $3,84 \pm 0,23$ & $12,0 \pm 1,0$ & $8,63 \pm 0,97$ & $6,11 \pm 0,84$ & $5,19 \pm 0,61$ & $312,1 \pm 28,4$ \\
\hline Контроль & $3,87 \pm 0,23$ & $13,7 \pm 1,3$ & $9,97 \pm 1,55$ & $6,35 \pm 1,00$ & $5,25 \pm 0,55$ & $345,5 \pm 37,2$ \\
\hline $\begin{array}{c}\beta \text {-ФЕА-ОСАК } \\
(25 \text { мг/кг) }\end{array}$ & $3,98 \pm 0,17$ & $13,5 \pm 1,1$ & $10,9 \pm 1,3$ & $6,51 \pm 1,22$ & $5,46 \pm 0,88$ & $356,0 \pm 35,4$ \\
\hline
\end{tabular}

Прилітка.

1) ППК - площа під глікемічною кривою.

Таблиця 2

Оцінка антиокислювальної активності 2-ГФСА, $\beta$-ФЕСА та $\beta$-ФЕАОСАК in vitro, $n=5,\left(\overline{\mathrm{X}} \pm \mathrm{S}_{\overline{\mathrm{X}}}\right)$

\begin{tabular}{|c|c|c|c|}
\hline \multirow{2}{*}{$\begin{array}{c}\text { Концентрація } \\
\text { сполук, мкМ }\end{array}$} & 2-ГФСА & $\beta$-ФЕСА & ß-ФЕАОСАК \\
\hline & \multicolumn{3}{|c|}{ Сумарна антиокислювальна активність, \% } \\
\hline 25 & $5,6 \pm 1,4^{*}$ & $4,6 \pm 1,4^{*}$ & $26,4 \pm 2,3$ \\
\hline 50 & $7,9 \pm 1,5^{*}$ & $4,8 \pm 0,2^{*}$ & $29,1 \pm 3,2$ \\
\hline 100 & $9,6 \pm 0,8^{*}$ & $13,1 \pm 2,1^{*} \#$ & $30,3 \pm 1,3$ \\
\hline 150 & $14,5 \pm 2,1^{*}$ & $19,1 \pm 1,1^{*}$ & $38,1 \pm 1,2$ \\
\hline 200 & $18,7 \pm 1,4^{*}$ & $22,5 \pm 0,8^{*} \#$ & $48,8 \pm 1,4$ \\
\hline 250 & $26,0 \pm 0,3^{*}$ & $31,2 \pm 1,7 * \#$ & $71,9 \pm 2,9$ \\
\hline 300 & $34,6 \pm 1,1^{*} \#$ & $30,0 \pm 1,4^{*}$ & $71,4 \pm 1,6$ \\
\hline 350 & $23,8 \pm 1,8^{*}$ & $20,9 \pm 0,3^{*}$ & $72,9 \pm 1,9$ \\
\hline 400 & $20,4 \pm 0,9 *$ & $18,4 \pm 1,5^{*}$ & $75,0 \pm 0,9$ \\
\hline 500 & $15,8 \pm 1,5^{*}$ & $12,1 \pm 1,0 *$ & $78,2 \pm 1,2$ \\
\hline
\end{tabular}

Прилітки.

* $\mathrm{P} \leq$ 0,001 - вірогідні відмінності з групою В-ФЕАОСАК у відповідних концентраціях;

\# $\mathrm{P} \leq 0,05$ - вірогідні відмінності групи 2-ГФСА з групою 8-ФЕСА у відповідних концентраціях. 
перевищуючи ефрект кожного із метаболітів. На рівні більш високих концентрацій в діапазоні 350-500 мкМ ступінь прояву АОА $\beta$-ФЕАОСАК помітно не відрізняеться від значень даного параметру на рівні 250 мкM і 300 мкM.

За умов присутності в інкубаційному середовищі з суспензією ЖЛП обох метаболітів $\beta$-ФЕАОСАК в концентраціях від 50 мкМ до 150 мкМ зареєстровано збільшення антиокислювального ефекту максимально до $66,4 \%$, що помітно вище, ніж при введенні кожного з них окремо та при ізольованому введенні їх вихідної сполуки (рис. 1). Отже, сумісну дію 2-ГФСА та $\beta$-ФЕСА в зазначених концентраціях можна охарактеризувати як більше ніж адитивну, що супроводжується посиленням AОА. За умов сумісного впливу 2-ГФСА та $\beta$-ФЕСА в концентрації 200 мкМ також спостерігається сумація їх антиокислювального едекту, що може свідчити про ідентичність характеру біологічної дії сполук та загальний механізм їх дії. При одночасному впливі обох метаболітів у концентраціях 250-300 мкM, на рівні яких АOA кожного з них є максимальною, загальний антиокислювальний ефект є дещо нижчим за підсумований від їх дії окремо. Проте АОА $\beta$-ФЕАОСАК в цих концентраціях майже у два рази є більш вираженою порівняно 3 комбінацією його метаболітів (див. рис. 1). Можна припустити, що пригнічення ВРО на рівні відносно більш високих концен- трацій обумовлено саме дією $\beta$-ФЕАОСАК, як найбільш сильного антиоксиданта.

Отже, за даних умов експерименту антиокислювальний ефект 2-ГФСА та $\beta$-ФЕСА можна оцінити як помірно виражений, за ступенем виразності якого $\beta$ ФЕСА достовірно перевершуе інший метаболіт в діапазоні 100-250 мкМ. Проте обидва метаболіти в умовах in vitro значно поступаються за цим критерієм $\beta$-ФЕАОСАК в дослідженому діапазоні концентрацій. При комбінованій дії метаболітів у відносно невисоких концентраціях лінійного діапазону їх AOA помітно посилюеться.

Встановлено, що залежність AOA досліджених сполук від концентрації має лінійний характер у певному діапазоні: 100-300 мкМ для 2-ГФСА, 50-250 мкM $\beta$-ФЕСА, $100-250$ мкМ - $\beta$-ФЕАОСАК, 50-150 мкМ - 2-ГФСА + $\beta$-ФЕСА (рис. 1), та добре апроксимується рівнянням лінійної регресіі:

$$
\mathrm{I} \%=\mathrm{aC}+\mathrm{b}(\mathrm{r}=0,95 \div 0,97),
$$

де I - ефект інгібування утворення ТБКАС (\%);

a - вільний член, розрахований за результатами градуювальних розчинів;

C - концентрація сполуки в інкубаційному середовищі;

b - коефіцієнт регресії, розрахований за результатами градуювальних розчинів; $\mathrm{r}$ — коефіцієнт розведення при депротеїнізації.

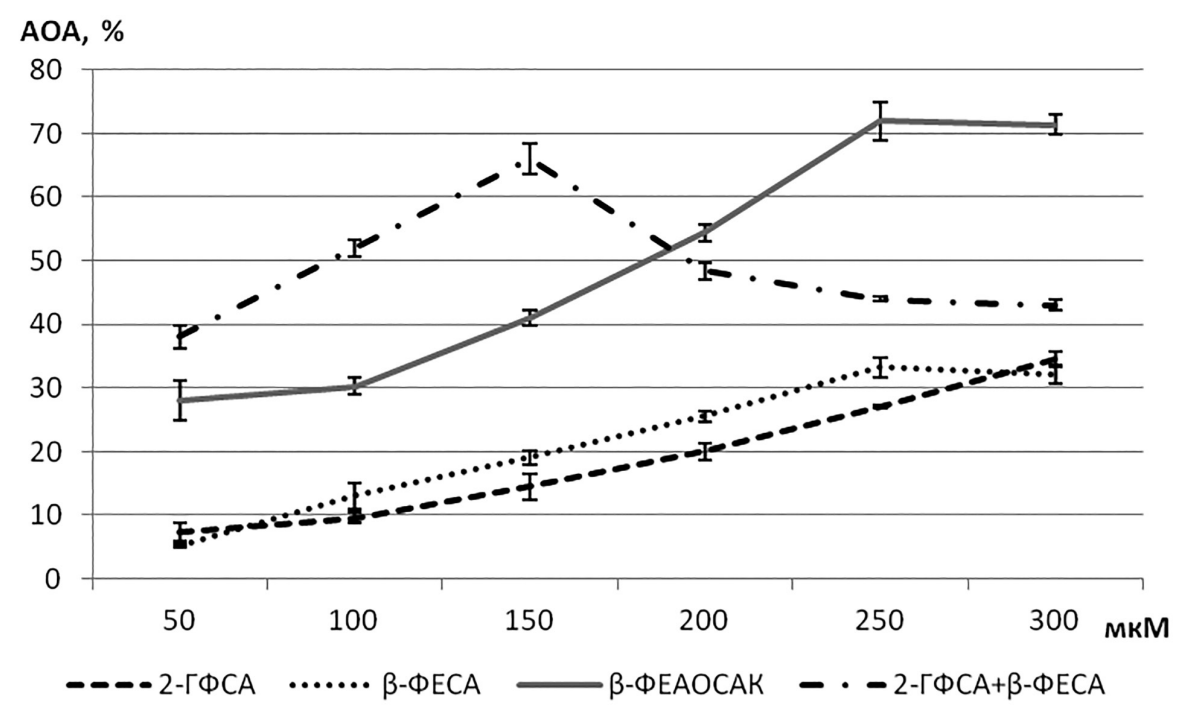

Рис. 1. Антиокислювальний ефект сполук (\% інгібування утворення ТБКАС у суспензії ЖЛП) 3 ділянками його лінійної залежності від концентрації в інкубаційному середовищі. 
Антиокислювальний ефектметаболітів $\beta$-ФЕАОСАК в залежності від концентрації, (I \% = aC + b)

\begin{tabular}{|c|c|c|c|c|c|}
\hline \multirow{2}{*}{ Сполука } & \multicolumn{5}{|c|}{ 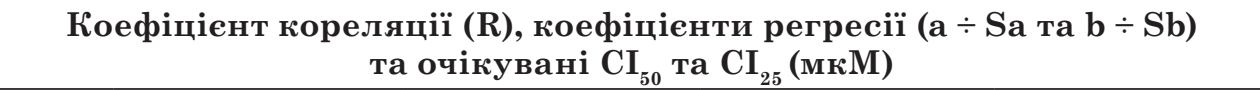 } \\
\hline & $\mathbf{R}$ & $\mathbf{a} \div \mathbf{S a}$ & $\mathbf{b} \div \mathbf{S b}$ & $\begin{array}{c}\mathrm{CI}_{50} \\
{[-95 \% ; 95 \% \mathrm{CI}]}\end{array}$ & $\begin{array}{c}\mathrm{CI}_{25} \\
{[-95 \% ; 95 \% \mathrm{CI}]}\end{array}$ \\
\hline 2-ГФСА & 0,96 & $-4,00 \div 1,824$ & $0,123 \div 0,009$ & $\begin{array}{c}419,08 \\
{[385,47 ; 452,7,]^{*}}\end{array}$ & $\begin{array}{c}232,52 \\
{[221,5 ; 243,5]^{*}}\end{array}$ \\
\hline В-ФЕСА & 0,96 & $-0,553 \div 1,45$ & $0,125 \div 0,009$ & $\begin{array}{c}385,0 \\
{[349,0 ; 385,0]^{*}}\end{array}$ & $\begin{array}{c}200,7 \\
{[188,2 ; 213,1]^{*}}\end{array}$ \\
\hline В-ФЕА-ОСАК & 0,95 & $0,519 \div 4,106$ & $0,268 \div 0,023$ & $\begin{array}{c}183,3 \\
{[173,2 ; 193,4]}\end{array}$ & $\begin{array}{c}99,2 \\
{[82,9 ; 115,4]}\end{array}$ \\
\hline
\end{tabular}

Примітка.

* $\mathrm{P}<0,05$ порівняно з В-ФЕАОСАК.

Для порівняння антиокислювального ефекту $\beta$-ФЕАОСАК та його метаболітів також використовували такі критерії, як очікувані концентрації сполуки, що призводять до 25 та $50 \%$ інгібування утворення ТБКАС $\left(\mathrm{CI}_{25}, \mathrm{CI}_{50}\right)$, які розраховували за допомогою регресійної моделі [11] (табл. 3).

При порівняльному аналізі за критеріем $\mathrm{CI}_{25}$ сполуки 2-ГФСА та $\beta$-ФЕСА мають приблизно вдвічі менш виражені антиоксидантні властивості, ніж $\beta$-ФЕАОСАК. Проте використання цих критеріїв можливе суто для оріентовної оцінки АОА метаболітів порівняно з їх вихідною сполукою, оскільки, враховуючи експериментально встановлені діапазони лінійної залежності антиокислювальний ефект-концентрація, розрахункові значення $\mathrm{CI}_{50}$ для 2-ГФСА та $\beta$-ФЕСА, $\mathrm{CI}_{25}$ для $\beta$-ФЕАОСАК експериментально встановити на обраній моделі in vitro не представляеться можливим.

В результаті досліджень встановлено, що 2-ГФСА та $\beta$-ФЕСА, як і $\beta$-ФЕАОСАК, не проявляють антигіперглікемічної активності в тесті толерантності до глюкози на інтактних щурах. Специфічну активність $\beta$-ФЕАОСАК визначено на моделях діабету з індукованою у щурів відносною та абсолютною інсуліновою недостатностю за рахунок ушкодження $\beta$-клітин панкреатичних острівців [6].

В дослідах in vitro показано, що метаболіти $\beta$-ФЕАОСАК здатні проявляти помірно виражені антиоксидантні властивості в умовах їх ізольованого надходження. За ступенем сумарної АОА $\beta$-ФЕСА дещо перевершуе 2-ГФСА, за розрахунковими критеріями $\mathrm{CI}_{50}$ та $\mathrm{CI}_{25}$ мало відрізняються один від одного, але обидва метаболіти е менш активними, ніж їх вихідна сполука. За умов комбінованої дії метаболітів їх антиокислювальна дія посилюеться та у відносно низьких досліджуваних концентраціях відмічаеться лінійна залежність зростання ступеня ефекту. Проте на рівні відносно високих досліджених концентрацій (більше 200 мкM) антиокислювальний ефект $\beta$-ФЕАОСАК значно перевищуе такий, що спостерігається при сумісному впливі його метаболітів. Отже, у прояв антиоксидантної дії $\beta$-ФЕАОСАК, що залежить від концентрації, певний внесок можуть робити метаболіти першої фази його біотрансформаціі, які мають односпрямовану дію та викликають адитивний антиокислювальний ефект в певному діапазоні концентрацій.

\section{ВИСНОВКИ}

1. 2-гідроксифенілсукцинамід та $\beta$-фенілетилсукцинамід - метаболіти першої фази біотрансформації антидіабетичного засобу $\beta$-фенілетиламіда 2 -оксисукцинанілової кислоти, як і їх вихідна сполу- ка, не проявляють антигіперглікемічної активності у інтактних щурів із одноразовим пероральним глюкозним навантаженням. 
2. У тесті in vitro ізольовано 2-гідроксифенілсукцинамід та $\beta$-фенілетил-сукцинамід иказують помірно виражений антиокислювальний ефект, поступаючись $\beta$-ренілетиламіду 2 -оксисукцинанілової кислоти. За умов сумісної присутності цих метаболітів антиокислювальний ефект посилюеться внаслідок їх комбінованої дії, яка, в залежності від концентрації, має адитивний характер.

\title{
ЛITEPATУРA \\ (REFERENCES)
}

1. International Diabetes Federation. Diabetes Atlas, Brussels, 2019; 9th ed: 168 p.

7. Guengerich FP. Drug Metab Pharmacokinet 2011; 26(1): 3-14.

2. Zheng Y., Ley S.H., Hu F.B. Nat Rev Endocrinol 2018; 14(2): 88-98. doi: 10.1038/ nrendo.2017.151.

3. Bodnar PM. Endokrynologija : pidruchnyk dlja studentiv vyshhyh medychnyh navchal'nyh zakladiv, Vinnycja, 2017: $456 \mathrm{p}$.

4. Lenzen S. Biochem Biophys Acta Gen Subj 2017; 1861(8): 1929-1942. doi: https://doi.org/10.1016/ j.bbagen. 2017.05.013.

5. Rajendiran D, Packirisamy S, Gunasekaran K. Asian $J$ Pharmaceut Clin Res 2018; 11(2): 48-53. doi: http:// doi:10.22159/ajpcr.2018.v11i2.23241.

6. GorbenkoNI, Poltorak VV. Endokrynologija 2002; 7(2): 233-241.

8. Doklinicheskie issledovanija lekarstvennyh sredstv : metod. Rekomendaciï, pod red. AV. Stefanova, Kiev, 2002: 568 p.

9. Klebanov GI, Babenkova IV, Teselkin JuO, et al. Lab Delo 1988; 5: 59-62.

10. Atramentova LA, Utevskaja LA. Statisticheskie metody v biologii: uchebnik dlja studentov VUZov, Gorlovka, 2008: $248 \mathrm{p}$.

11. Borikov OJu. Visnyk Farmacii' 2010; 3(63): 73-75.

\section{ПОРІВНЯЛЬНА ОЦІНКА АНТИГІПЕРГЛІКЕМІЧНОЇ ТА АНТИОКИСЛЮВАЛЬНОÏ АКТИВНОСТІ МЕТАБОЛІТІВ СУКЦИНАТВМІСНОГО АНТИДІАБЕТИЧНОГО ЗАСОБУ}

\author{
Палагіна I. А.
}

ДУ «Інститут проблем ендокринної патологї̈ ім. В. Я. Данилевського НАМН України», м. Харків, Україна

lab-tox@ukr.net

Новий вітчизняний антидіабетичний засіб розроблено на основі $\beta$-ренілетиламіда 2 -оксисук-

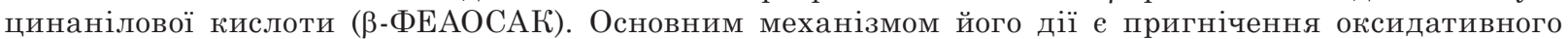
стресу, стимуляція біоенергетичної активності мітохондрій та зниження неферментативного глікозилювання. Метаболітами першої фрази біотрансформації $\beta$-ФЕАОСАК є 2-гідроксифеніл- (2-ГФСА) і $\beta$-френілетилсукцинамід ( $\beta$-ФЕСА), які можуть відігравати певну роль у механізмі антидіабетичної дії ціеї сполуки.

Мета дослідження - оцінити антиокислювальний та антигіперглікемічний потенціал 2-гідроксифеніл- та $\beta$-фенілетилсукцинаміда порівняно з їх вихідною сполукою - $\beta$-фенілетиламідом 2 -оксисукцинанілової кислоти.

Антигіперглікемічну активність сполук визначали в тесті толерантності до глюкози на щурах, яким вводили 2-ГФСА і $\beta$-ФЕСА перорально в дозах 17 мг/кг м.т., 18 мг/кг м.т, які еквімолярні ефрективній дозі $\beta$-ФЕАОСАК, що дорівнюе 25 мг/кг м.т. Рівень глікемії оцінювали за показниками базальної глікемії та площі під глікемічною кривою. Дослідження антиокислювальної активності метаболітів $\beta$-ФЕАОСАК проведено in vitro на суспензії жовточних ліпопротеїдів шляхом визначення вмісту активних сполук, що реагують з тіобарбітуровою кислотою, у системі з антиоксидантом та без нього. Досліджені концентрації сполук в інкубаційному середовищі знаходились в діапазоні $25-500$ мкМ. $\beta$-ФЕАОСАК служила сполукою порівняння, яку застосовували у таких же концентраціях.

Встановлено, що 2-ГФСА та $\beta$-ФЕСА, як і $\beta$-ФЕАОСАК, не проявляють антигіперглікемічної активності в тесті толерантності до глюкози. Метаболіти $\beta$-ФЕАОСАК in vitro в умовах їх ізольованого надходження демонструють помірно виражений антиокислювальний ефект, який за умов їх комбінованої дії посилюеться та має адитивну залежність у певному діапазоні концентрацій. За ступенем антиоксидантної активності $\beta$-ФЕСА достовірно перевершуе інший метаболіт в діапазоні концентрацій 100-250 мкМ. Проте обидва метаболіти, навіть при сумісному впливі, поступаються за ступенем сумарної антиокислювальної активності $\beta$-ФЕАОСАК, яка є їх вихідною сполукою. 
Отже, метаболіти першої фрази біотрансформаціі $\beta$-ренілетиламіда 2 -оксисукцинанілової кислоти 2 -гідроксифенілсукцинамід та $\beta$-фенілетилсукцинамід, не виказують антигіперглікемічної активності, але in vitro проявляють антиоксидантну дію та роблять певний внесок у прояв антиокислювального ефекту їх вихідної сполуки.

К лючові слова: метаболіти сукцинатвмісного антидіабетичного засобу, антигіперглікемічна та антиокислювальна активність.

\title{
COMPARATIVE ASSESSMENT OF ANTI-HYPERGLYCEMIC AND ANTI-OXIDATIVE ACTIVITY OF METABOLITES OF THE SUCCINATE-CONTAINING ANTIDIABETIC DRUG
}

\author{
Palagina I. A. \\ SI «V. Danilevsky Institute of Endocrine Pathology Problems \\ of the NAMS of Ukrainen, Kharkov, Ukraine \\ lab-tox@ukr.net
}

A new domestic antidiabetic medicine has been developed based on the $\beta$-phenylethylamide of 2 -oxysuccinanil acid ( $\beta$-PhEA-OSAA). The main mechanism of its action embraces the oxidative stress inhibition, stimulation of the bioenergetic activity in mitochondria and decrease in non-enzymatic glycosylation. The first phase metabolites of $\beta$-PhEA-OSAA biotransformation are the 2-hydroxyphenylsuccinamide (2-HPhSA) and $\beta$-phenylethylsuccinamide ( $\beta$-PhESA) which may play a certain part in mechanism of the antidiabetic action of this compound.

The aim of our study was to evaluate the anti-oxidative and anti-hyper-glycemic potential of 2-hydroxyphenyl- and $\beta$-phenylethylsuccinamide compared to their parent compound, $\beta$-phenylethylamide of 2 -oxysuccinanil acid.

The anti-hyperglycemic activeness of these compounds was determined in a glucose tolerance test in rats, which were orally introduced 2-HPhSA and $\beta$-PhESA in doses $17 \mathrm{mg} / \mathrm{kg}$ b.w. and $18 \mathrm{mg} / \mathrm{kg}$ b.w. These doses are equimolar to the effective dose of $\beta$ - PhEA-OSAA, which is $25 \mathrm{mg} / \mathrm{kg}$ b.w. The glycemic level was assessed by parameters of the basal glycemia and the area under the glycemic curve. The study of the anti-oxidative activity of $\beta$-PhEA-OSAA metabolites was made in vitro using a suspension of yolk lipoproteins. We were determining the content of active compounds that react with the thiobarbituric acid in the system with an antioxidant and without it. The tested concentrations of compounds in the incubation medium were ranged from $25 \mu \mathrm{M}$ to $500 \mu \mathrm{M}$. $\beta$-PhEA-OSAA served as a reference compound which was tested at the same concentrations.

We have found that 2-HPhSA and $\beta$-PhESA, as well as $\beta$-PhEA-OSAA, do not exhibit any anti-hyperglycemic activity in the glucose tolerance test.

Besides in vitro both of $\beta$-PhEA-OSAA metabolites proved to show a moderately expressed anti-oxidative effect which, under their combined influence, was enhanced and had an additive dependence within a certain concentration range. $\beta$-PhESA significantly exceeds the second metabolite by the degree of its antioxidant activity at the concentration range of 100-250 $\mathrm{MM}$. However, both metabolites, even with a joint impact, were inferior to $\beta$-PhEA-OSAA (their parent compound) by the degree of the total antioxidant activity.

Thus, we have substantiated that the first phase metabolites of the $\beta$-phenylethylamide of 2 -hydroxysuccinanilic acid biotransformation (2-hydroxyphenyl-succinamide and $\beta$-phenylethylsuccinamide) do not exhibit the anti-hyperglycemic activity, but in vitro they possess the antioxidant effect and make a certain contribution to intensity of the anti-oxidative effect of their parent compound.

Key words: metabolites of a succinate-containing antidiabetic medicine, anti-hyperglycemic and antioxidative activity. 